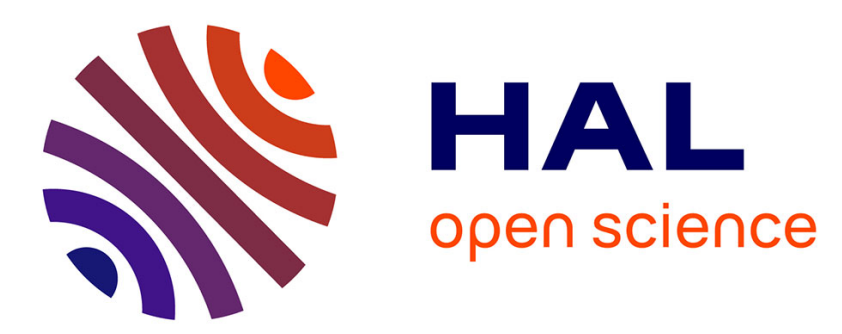

\title{
Evidence for the formation of UO2(NO3)42- in an ionic liquid by EXAFS
}

\author{
Clotilde Gaillard, Olga Klimchuk, Ali Ouadi, Isabelle Billard, Christoph \\ Hennig
}

\section{- To cite this version: \\ Clotilde Gaillard, Olga Klimchuk, Ali Ouadi, Isabelle Billard, Christoph Hennig. Evidence for the formation of UO2(NO3)42- in an ionic liquid by EXAFS. Dalton Transactions, 2012, 41 (18), pp.5476- 5479. 10.1039/c2dt30205e . hal-02271628}

\section{HAL Id: hal-02271628 \\ https://hal.science/hal-02271628}

Submitted on 27 Aug 2019

HAL is a multi-disciplinary open access archive for the deposit and dissemination of scientific research documents, whether they are published or not. The documents may come from teaching and research institutions in France or abroad, or from public or private research centers.
L'archive ouverte pluridisciplinaire HAL, est destinée au dépôt et à la diffusion de documents scientifiques de niveau recherche, publiés ou non, émanant des établissements d'enseignement et de recherche français ou étrangers, des laboratoires publics ou privés. 


\title{
EVIDENCE FOR THE FORMATION OF UO ${ }_{2}\left(\mathrm{NO}_{3}\right)_{4}{ }^{2-}$ IN AN IONIC LIQUID BY EXAFS
}

\author{
Clotilde Gaillard, ${ }^{1 *}$ Olga Klimchuk, ${ }^{2,3}$ Ali Ouadi, ${ }^{2}$ Isabelle Billard ${ }^{2}$, Christoph Hennig $^{4}$ \\ ${ }^{1}$ University of Lyon, Institut de Physique Nucléaire de Lyon, CNRS-IN2P3, 69622 Villeurbanne \\ cedex, France.*corresponding author : c.gaillard@ipnl.in2p3.fr \\ 2 Institut Pluridisciplinaire Hubert Curien, DRS, Chimie Nucléaire, 23 rue du Lœss, 67037 \\ Strasbourg cedex 2, France. \\ ${ }^{3}$ Institute of Organic Chemistry, NAS of Ukraine, 02660, Murmanska, 5, Kyiv, Ukraine. \\ ${ }^{4}$ Institute of Radiochemistry, Forschungszentrum Dresden-Rossendorf, P.O. Box 510119, \\ 01314 Dresden, Germany.
}

\begin{abstract}
The complexation between uranium (VI) and nitrate ions in an hydrophobic ionic liquid (IL), namely $[\mathrm{BMI}]\left[\mathrm{NO}_{3}\right]\left(\mathrm{BMI}=1\right.$-butyl-3-methylimidazolium $\left.{ }^{+}\right)$, is investigated by EXAFS spectroscopy. It was performed by dissolution of uranyl nitrate $\mathrm{UO}_{2}\left(\mathrm{NO}_{3}\right)_{2} \cdot 6 \mathrm{H}_{2} \mathrm{O}$ or $\mathrm{UO}_{2}\left(\mathrm{Tf}_{2} \mathrm{~N}\right)_{2}$ $\left(\mathrm{Tf}_{2} \mathrm{~N}=\right.$ bis(trifluoromethylsulfonyl)imide $\left.\left(\mathrm{CF}_{3} \mathrm{SO}_{2}\right)_{2} \mathrm{~N}^{-}\right)$. The formation of the complex $\mathrm{UO}_{2}\left(\mathrm{NO}_{3}\right)_{4}{ }^{2-}$ is evidenced.
\end{abstract}

Ionic liquids (ILs) have been widely studied for the last decade in all fields of chemistry, and were shown to be powerful media for electrochemistry or catalysis for instance. ${ }^{1-3}$ Many researches on IL are led with the aim to use them in replacement of toxic organic solvents used in industrial processes. ${ }^{4}$ The IL ionic nature entails different solute-solvent interactions which can have direct consequences on the chemical reactivity of species or on extraction mechanisms. For instance, it was shown that using an hydrophobic IL $[\mathrm{BMI}]\left[\mathrm{Tf}_{2} \mathrm{~N}\right]$ instead of an organic solvent (dodecane) entails a change in the extracted species stoechiometry during uranium (VI) leaching from an acidic aqueous phase to the IL/organic phase. ${ }^{5}$ Also, the choice of the IL cation and anion may have an influence on the phenomena: the IL cation alkyl chain length has a direct influence on the extraction mechanism of uranium from an acidic aqueous phase to an IL phase, the U(VI) extraction being performed either by an ion-exchange mechanism or the formation of neutral species. ${ }^{6}$ The large interest in the chemistry of lanthanides and actinides in ionic liquids arises from the fact that ILs could constitute an interesting alternative to the organic solvents (kerosene) used nowadays for the nuclear fuel reprocessing. Those researches deal with the field of liquid-liquid extraction, ${ }^{6-9}$ but aim also at gaining fundamental data on solute-solvent interaction and solute solvation and complexation in these new media. ${ }^{10-15}$

Fundamental interactions between f-elements and various ligands (nitrate, chloride, perchlorate) in hydrophobic IL have been investigated for several years. ${ }^{16-24}$ In particular, nitrate ions are of interest as they are present in large quantities during the nuclear fuel reprocessing. They are known to be slightly complexant to uranium(VI) in water as species formed are mainly the $\mathrm{U}: \mathrm{NO}_{3}$ 1:1 complex. ${ }^{25}$ In organic solvents like acetonitrile or acetone, nitrate ions are strong complexants to uranyl. We define here as strong $\mathrm{X}^{-}$ligand a ligand forming at almost $100 \%$ the $\left[\mathrm{UO}_{2}(\mathrm{X})_{\mathrm{n}}\right]^{2-\mathrm{n}}$ species at $\mathrm{R}=\left[\mathrm{X}^{-}\right] /\left[\mathrm{UO}_{2}{ }^{2+}\right]$ values equal to $\mathrm{n}(\mathrm{n}=1$ up to the limiting complex $)$. Many authors have shown that the nitrate complexation to uranium (VI) leads to the formation of 
the complex $\mathrm{UO}_{2}\left(\mathrm{NO}_{3}\right)_{3}{ }^{-}$when the $\left[\mathrm{NO}_{3}{ }^{-}\right] /\left[\mathrm{UO}_{2}{ }^{2+}\right]$ ratio is equal or above $3 .^{26-29}$ This $1: 3$ complex is usually considered as the limit complex in the liquid state. The formation of species with a higher stoechiometry (ie. 1:4) has never been proved, although its existence was postulated by theoretical calculations. ${ }^{30}$ In ionic liquid, the study of this ionic complexation can go one step further. First, it is easier to get rid of species that can potentially interfere with the complexation reaction to be studied. Those species can be the residual water (highly complexant to uranium) or counter-ions that are solubilized with uranium or nitrates in solution. Those difficulties can be overcome in IL by using uranyl and nitrate salts that display counter-anions and counter-cations identical to the IL anion and cation. Moreover, the IL low volatility renders them easier to dry than organic solvents. Another advantage of IL is that the concentration of dissolved species can be higher, just by choosing the right IL that would be the solvent and the reactant in the same time.

So far, only one attempt to characterize $\mathrm{UO}_{2}\left(\mathrm{NO}_{3}\right)_{4}{ }^{2-}$ species in solution was made, by Bradley et al., ${ }^{31}$ using EXAFS spectroscopy. First, they dissolved $\mathrm{UO}_{2}\left(\mathrm{NO}_{3}\right)_{2} \cdot 6 \mathrm{H}_{2} \mathrm{O}$ in $[\mathrm{BMI}]\left[\mathrm{NO}_{3}\right]$. No indication on the water content of the solution was given, but the authors took into account the coordination of water molecules to uranyl to get the best fit. They conclude that species present in solution are likely $\left[\mathrm{UO}_{2}\left(\mathrm{NO}_{3}\right)_{3} \cdot \mathrm{H}_{2} \mathrm{O}\right]^{-}$, and not the $1: 4$ complex $\mathrm{UO}_{2}\left(\mathrm{NO}_{3}\right)_{4}{ }^{2-}$. They also performed an oxidative dissolution of $\mathrm{UO}_{2}$ in $[\mathrm{BMI}]\left[\mathrm{NO}_{3}\right]$ in presence of aqueous $\mathrm{HNO}_{3}$, and conclude that this solution should be constituted of a mixture of different species, involving the $\mathrm{U}: \mathrm{NO}_{3}{ }^{-}$1:4 complex and hydrated nitrato-complexes.

In the present work, we have chosen to work with a highly pure and dry hydrophobic IL $[\mathrm{BMI}]\left[\mathrm{NO}_{3}\right]$ (BMI = 1-butyl-3-methyl imidazolium cation), in which we have dissolved either $\mathrm{UO}_{2}\left(\mathrm{NO}_{3}\right) \cdot 6 \mathrm{H}_{2} \mathrm{O}$ or $\mathrm{UO}_{2}\left(\mathrm{Tf}_{2} \mathrm{~N}\right)_{2}\left(\mathrm{Tf}_{2} \mathrm{~N}^{-}=\right.$bis(trifluoromethylsulfonyl)imide $\left.\left(\mathrm{CF}_{3} \mathrm{SO}_{2}\right)_{2} \mathrm{~N}^{-}\right)$. In those IL solutions, the $\left[\mathrm{NO}_{3}{ }^{-}\right] /\left[\mathrm{UO}_{2}{ }^{2+}\right]$ ratio is equal to 600 , which cannot be achieved in organic solvents for an uranium concentration of $0.01 \mathrm{M}$. After degassing in order to remove any residual water, solutions were analyzed by EXAFS spectroscopy (see experimental details in supplementary information).

EXAFS spectra for the two $[\mathrm{BMI}]\left[\mathrm{NO}_{3}\right]$ solutions $\left(\mathrm{UO}_{2}\left(\mathrm{Tf}_{2} \mathrm{~N}\right)_{2}\right.$ and uranyl nitrate) are displayed on figure 1, with their corresponding Fourier Transform. They are compared with the spectra of $\mathrm{UO}_{2}\left(\mathrm{NO}_{3}\right)_{3}{ }^{-}$and $\mathrm{UO}_{2}\left(\mathrm{NO}_{3}\right)_{2}$ complexes, as obtained in IL [BMI][Tf $\left.2 \mathrm{~N}\right]$ solutions characterized previously by EXAFS and UV-vis spectroscopies. ${ }^{20}$

On the Fourier transforms, the first peak centered at $\mathrm{R}+\Delta \sim 1.4 \AA$ corresponds to the presence of 2 axial oxygen atoms, which also entail the presence of the contribution at $\mathrm{R}+\Delta \sim 3 \AA$ (multiple scattering interactions between $\mathrm{U}$ and axial $\mathrm{O}$ ). The two peaks centered before and after $\mathrm{R}+\Delta \sim$ $2 \AA$ correspond to the equatorial oxygen shell of uranium (VI).

At longer distances from uranium, contributions visible on the FT depend on the number of nitrate groups and their coordination mode. At this point, it must be necessary to recall the structure of the considered species. $\mathrm{UO}_{2}\left(\mathrm{NO}_{3}\right)_{2}$ and $\mathrm{UO}_{2}\left(\mathrm{NO}_{3}\right)_{3}{ }^{-}$complexes are formed with respectively 2 and 3 nitrate groups bound in a bidentate fashion in the equatorial sphere of uranyl. This implies the presence of several features on the FT spectra (figure 1b). The peak at $\mathrm{R}+\Delta \sim 2.6 \AA$ is due to the presence of $\mathrm{U}-\mathrm{N}$ single scattering interactions from bidentate nitrate groups, its intensity is directly proportional to the number of bidentate $\mathrm{NO}_{3}$ as shown in ${ }^{20}$. The contribution visible at $\mathrm{R}+\Delta \sim 3.8 \AA$ corresponds to the presence of the distal oxygen of bidentate nitrate groups (single and multiple scatterings).

In the solid structure of $\left[\mathrm{UO}_{2}\left(\mathrm{NO}_{3}\right)_{4}\right]^{2-}$, uranium is complexed by two bidentate nitrate groups and two monodentate nitrate groups, i.e. it can be written $\left[\mathrm{UO}_{2}\left(\eta^{2}-\mathrm{NO}_{3}\right)_{2}\left(\eta^{1}-\mathrm{NO}_{3}\right)_{2}\right]^{2-}$. Figure S1 (supplementary information) displays the structure of this complex. The monodentate 
nitrate group entails the presence of other contributions, as detailed in Table 1 which summarizes the main paths to be taken into account for fitting the complex $\left[\mathrm{UO}_{2}\left(\eta^{2}-\mathrm{NO}_{3}\right)_{2}\left(\eta^{1}-\mathrm{NO}_{3}\right)_{2}\right]^{2-}$.

We have shown in previous studies that when the ratio $\left[\mathrm{NO}_{3}\right] /[\mathrm{U}]$ was equal or superior to 3 in $[\mathrm{BMI}]\left[\mathrm{Tf}_{2} \mathrm{~N}\right]$, then the main species present in solution is the 1:3 complex, formed with 3 bidentate nitrate groups. On this basis, considering that in the present solutions this ratio is almost equal to 600, we could expect the exclusive presence of the 1:3 complex. Nevertheless, observation of the EXAFS and FT spectra can already give some doubt on this. We can observe that the two EXAFS spectra obtained for the $[\mathrm{BMI}]\left[\mathrm{NO}_{3}\right]$ solutions are identical, but are slightly different to those observed for $\mathrm{U}: \mathrm{NO}_{3} 1: 2$ and 1:3 complexes. On the EXAFS, this is visible in the 5-8 $\AA^{-1}$ region, and even more clearly on the corresponding FTs. When looking at the peak located at $\mathrm{R}+\Delta \sim 2.6 \AA$, we can see that its intensity for the $[\mathrm{BMI}]\left[\mathrm{NO}_{3}\right]$ solutions is closer to the one of the 1:2 complex than for the 1:3 complex. The same tendency is observed considering the position and intensity of the two peaks corresponding to the equatorial oxygens, at $\mathrm{R}+\Delta \sim 2 \AA$. Fitting of these spectra confirmed those observations. Considering the sole presence of $\mathrm{UO}_{2}\left(\mathrm{NO}_{3}\right)_{3}{ }^{-}$species did not lead to any satisfactory results. The best fit is obtained considering the complexation of two bidentate nitrate groups to uranyl, but it was necessary to add to the fit model the presence of monodentate ligands. For the $\mathrm{UO}_{2}\left(\mathrm{NO}_{3}\right)_{2} \cdot 6 \mathrm{H}_{2} \mathrm{O}$ solution in $[\mathrm{BMI}]\left[\mathrm{NO}_{3}\right]$, the only additional ligand possible is nitrate. For the $\mathrm{UO}_{2}\left(\mathrm{Tf}_{2} \mathrm{~N}\right)_{2}$ solution, this could be either nitrate from the IL or $\mathrm{Tf}_{2} \mathrm{~N}^{-}$introduced with uranium. The complexation of this latter anion to uranyl in the $[\mathrm{BMI}]\left[\mathrm{NO}_{3}\right]$ solution is highly improbable: many studies have shown that $\mathrm{Tf}_{2} \mathrm{~N}^{-}$ ions are very weak ligands to uranyl, and are easily removed from the first uranyl coordination sphere by various ions as perchlorate, chloride or nitrate ions. ${ }^{20,21,29,32}$ Thus, considering the high nitrate concentration in a $[\mathrm{BMI}]\left[\mathrm{NO}_{3}\right]$ solution and the relative strength of complexation of $\mathrm{Tf}_{2} \mathrm{~N}$ and nitrate groups, we can safely conclude that in the $\mathrm{UO}_{2}\left(\mathrm{Tf}_{2} \mathrm{~N}\right)_{2}$ solution, as in the uranyl nitrate solution, uranyl is complexed only by nitrates ions.

Best fit results are displayed in Table 2. According to the large number of unknown parameters to be fitted, we have added some constraints to the fit, in particular on the coordination numbers. First, the total number of equatorial oxygens was fixed to 6 . Then, coordination numbers of equatorial oxygen atoms, nitrogen atoms and distal oxygen atoms arising from monodentate groups were linked, the same procedure was applied for shells arising from bidentate nitrates. Multiple scatterings contributions from nitrate groups were also taken into account and their corresponding parameters were linked to those of single scatterings.

Fit results are similar for the two $[\mathrm{BMI}]\left[\mathrm{NO}_{3}\right]$ samples. The number of bidentate nitrates is found to be between 1.5 and 2, while the number of monodentate nitrates is between 2 and 3 , according to experimental uncertainties. From those results, we can conclude that the main species present in solution is the tetra-nitrato-complex of uranyl $\mathrm{UO}_{2}\left(\mathrm{NO}_{3}\right)_{4}{ }^{2-}$.

As explained in this paper introduction, only one attempt ${ }^{31}$ was made previously to characterize the $\mathrm{UO}_{2}\left(\mathrm{NO}_{3}\right)_{4}{ }^{2-}$ complex in the liquid state, by a similar experiment than ours, i.e. by dissolution of $\mathrm{UO}_{2}\left(\mathrm{NO}_{3}\right)_{2} \cdot 6 \mathrm{H}_{2} \mathrm{O}$ in the ionic liquid $[\mathrm{BMI}]\left[\mathrm{NO}_{3}\right]$. The authors had to take into account the presence of water molecule in the uranyl first coordination sphere. Moreover, some unusual features were obtained considering the structure of the characterized species. The uranyl to equatorial oxygen distance found for what is attributed to complexed water molecules is quite short, at $2.34 \AA$. This range of bond distance is unexpected in the liquid state, where it lies usually around $2.40-2.42 \AA{ }^{33}$ A $2.34 \AA$ distance is closer to the ones observed for bridging ligands in dimeric compounds, like in the dimeric anion $\left[\left(\mathrm{UO}_{2}\right)_{2}(\mu-\mathrm{OH})_{2}\left(\mathrm{NO}_{3}\right)_{4}\right]^{2-}$ characterized by Cocalia et al. ${ }^{34}$ This hypothesis was not discussed by the authors, although the analyzed solutions were rather concentrated in uranium $(0.4 \mathrm{M})$. Moreover, it has been shown that nitrates 
ions are stronger complexant to uranyl than water in hydrophobic IL, ${ }^{35}$ so that the residual water in solution should not be able to compete with a massive concentration of nitrates for the uranyl complexation.

In our case, the water content in solution was controlled and kept at a ratio $\left[\mathrm{H}_{2} \mathrm{O}\right] /[\mathrm{U}]$ below 0.4 , so that we can preclude de facto any water complexation to uranium. EXAFS structural parameters obtained for our two IL solutions evidence clearly the formation of $\mathrm{UO}_{2}\left(\mathrm{NO}_{3}\right)_{4}{ }^{2-}$ in both samples. The structural parameters obtained can also preclude the formation of dimeric species, as they would result in significantly smaller equatorial distances. ${ }^{34}$ Interatomic distances are in agreement with the coordination mode of nitrates. Let us first focus on bidentate nitrate groups: $\mathrm{U}_{-} \mathrm{O}_{\mathrm{eq}}$ distances, found at 2.53-2.54 $\AA$, are typical of this coordination mode of nitrates, as shown in ILs ${ }^{35}$ or in conventional organic solvents. ${ }^{26}$ The U-N distance, ranging between 2.92 and $2.97 \AA$, and the $\mathrm{U}-\mathrm{O}_{\text {distal }}$ distance of 4.19-4.20 $\AA$, are also commonly found for bidentate nitrates complexed to uranium (VI). Let us consider now the monodentate nitrate groups: $\mathrm{U}-\mathrm{O}_{\mathrm{eq}}$ distance lies at $2.40-2.41 \AA$, which is a typical value for a monodentate coordination of oxygenated ligand to uranyl, like water ${ }^{33}$ or $\mathrm{Tf}_{2} \mathrm{~N}^{-20}$. The $\mathrm{U}-\mathrm{N}_{\text {monodentate distances }}$ are quite different for the two samples $\left(3.27 \AA\right.$ for the $\mathrm{UO}_{2}\left(\mathrm{Tf}_{2} \mathrm{~N}\right)_{2}$ solution and $3.14 \AA$ for the uranyl nitrate solution) whereas the $\mathrm{U}-\mathrm{O}_{\text {dist-monodentate }}$ are the same, at 3.42-3.45 $\AA$. These bond distances are directly related to the spatial orientation of the nitrate group towards uranyl. Table 3 summarizes the bond distances and angles obtained in five published crystalline structure of $\left[\mathrm{UO}_{2}\left(\eta^{2}-\mathrm{NO}_{3}\right)_{2}\left(\eta^{1}-\mathrm{NO}_{3}\right)_{2}\right]^{2-}$ (solid state). ${ }^{31,36,37}$ Comparing the two structures published by Bradley et al., it is interesting to notice that the $\mathrm{U}-\mathrm{O}_{\text {distal }}$ distances for monodentate nitrate groups can be quite different (3.38 $\AA$ vs. $3.51 \AA$ ) while $\mathrm{U}-\mathrm{O}_{\mathrm{eq}}, \mathrm{U}-\mathrm{N}$ distances and the $\mathrm{O}_{\mathrm{eq}}-\mathrm{N}-\mathrm{O}_{\text {distal }}$ angle are identical. The explanation arises from a slight difference inside the nitrate group structure, with a $\mathrm{N}-\mathrm{O}_{\text {distal }}$ distance being respectively equal to $1.23 \AA$ and $1.21 \AA$. We thus see that slight variations in the monodentate nitrate structure (bond distance, angle) and in its orientation towards uranium can entail significant changes on the resulting structural parameters. The effect is less visible on bidentate groups as this coordination mode is less flexible.

A discussion can be led on the proportion between bidentate and monodentate ligands in the 1:4 complex. Looking at the coordination numbers found by the fit, our results are consistent with the major presence in our samples of $\left[\mathrm{UO}_{2}\left(\eta^{2}-\mathrm{NO}_{3}\right)_{2}\left(\eta^{1}-\mathrm{NO}_{3}\right)_{2}\right]^{2-}$. This would be in agreement with the structure calculated in water by molecular dynamics calculation ${ }^{30}$ and would mean that this complex exhibits the same structure in the IL than in the solid state. But considering uncertainties on the fit results, and the fact that EXAFS gives an average of the uranium coordination sphere in solution, we cannot neglect the minor presence in solution of another bidentate/monodentate combination, like $\left[\mathrm{UO}_{2}\left(\eta^{2}-\mathrm{NO}_{3}\right)\left(\eta^{1}-\mathrm{NO}_{3}\right)_{3}\right]^{2-}$. This result can be compared with the coordination of uranium (VI) in organic solvents. In acetonitrile, it is shown that when 2 nitrate ions complex to uranyl, they are in the bidentate mode and that the total coordination sphere of uranyl comprises 6 atoms: 4 from the bidentate nitrate groups, and 2 from the monodentate coordination of solvent molecule. ${ }^{26}$ We thus evidence the same uranyl coordination in our IL solutions, nitrate being the solvent molecules.

In conclusion, we have shown by EXAFS the formation of $\mathrm{UO}_{2}\left(\mathrm{NO}_{3}\right)_{4}{ }^{2-}$ in the liquid state for a high concentration of nitrate ions, achieved thanks to the use of the ionic liquid $[\mathrm{BMI}]\left[\mathrm{NO}_{3}\right]$ as solvent. According to our results, this 1:4 nitrato-complex of uranyl has a structure close to the one in the solid state with the coordination of 2 bidentate and 2 monodentate nitrate groups to uranyl. 


\section{ACKNOWLEDGMENTS}

This work is financially supported by the French ANR "LILAT". We acknowledge the European Synchrotron Radiation Facility for provision of synchrotron radiation facilities and we would like to thank the ROBL staff for assistance during experiments.

\section{REFERENCES}

1. A. K. Chakraborti and S. R. Roy, J. Am. Chem. Soc., 2009, 131, 6902.

2. C. P. Mehnert, R. A. Cook, N. C. Dispenziere and M. Afeworki, J. Am. Chem. Soc., 2002, 124, 12932.

3. H. Liu, Y. Liu and J. Li, Phys. Chem. Chem. Phys., 2010, 12, 1685.

4. R. D. Rogers and K. R. Seddon, Science, 2003, 302, 792.

5. I. Billard, A. Ouadi, E. Jobin, J. Champion, C. Gaillard and S. Georg, Solv. Extr. Ion Exch., 2011, 29, 577.

6. M. L. Dietz and D. C. Stepinski, Talanta, 2008, 75, 598.

7. M. P. Jensen, J. Neuefeind, J. V. Beitz, S. Skanthakumar and L. Soderholm, J. Am. Chem. Soc., 2003, 125, 15466.

8. V. A. Cocalia, M. P. Jensen, J. D. Holbrey, S. K. Spear, D. C. Stepinski and R. D. Rogers, Dalton Trans., 2005, 1966.

9. P. Giridhar, K. A. Venkatesan, S. Subramaniam, T. G. Srinivasan and P. R. V. Rao, J. Alloys Compd, 2008, 448, 104.

10. A. Babai, S. Pitula and A.-V. Mudring, Eur. J. Inorg. Chem., 2010, 4933.

11. A. I. Bhatt, N. W. Duffy, D. Collison, I. May and R. G. Lewin, Inorg. Chem., 2006, 45, 1677.

12. A. I. Bhatt, I. May, V. A. Volkovich, D. Collison, M. Helliwell, I. B. Polovov and R. Lewin, Inorg. Chem., 2005, 44, 4934.

13. E. Bossé, C. D. Auwer, C. Berthon, P. Guilbaud, M. S. Grigoriev, S. Nikitenko, C. L. Naour, C. Cannes and P. Moisy, Inorg. Chem., 2008.

14. C. Hardacre, J. D. Holbrey, M. Nieuwenhuyzen and T. G. A. Youngs, Acc. Chem. Res., 2007, 40, 1146.

15. A.-V. Mudring, A. Babai, S. Arenz, R. Giernoth, K. Binnemans, K. Driesen and P. Nockemann, J. Alloys Comp., 2006, 418, 204.

16. K. Binnemans, Chem. Rev., 2007, 107, 2592.

17. S. Stumpf, I. Billard, C. Gaillard, P. J. Panak and K. Dardenne, Radiochim. Acta, 2008, 96, 1 .

18. S. Stumpf, I. Billard, C. Gaillard, P. J. Panak and K. Dardenne, Inorg. Chem., 2008, 47, 4618.

19. C. Gaillard, I. Billard, A. Chaumont, S. Mekki, A. Ouadi, M. A. Denecke, G. Moutiers and G. Wipff, Inorg. Chem., 2005, 44, 8355.

20. C. Gaillard, A. Chaumont, I. Billard, C. Hennig, A. Ouadi, S. Georg and G. Wipff, Inorg. Chem., 2010, 49, 6484.

21. C. Gaillard, A. Chaumont, I. Billard, C. Hennig, A. Ouadi and G. Wipff, Inorg. Chem., 2007, 46, 4815.

22. S. Georg, I. Billard, A. Ouadi, C. Gaillard, L. Petitjean, M. Picquet and V. Solov'ev, J. Phys. Chem. B, 2010, 114, 4276.

23. A. E. Visser, M. P. Jensen, I. Laszak, K. L. Nash, G. R. Choppin and R. D. Rogers, Inorg. Chem., 2003, 42, 2197. 
24. I. Billard, S. Mekki, C. Gaillard, P. Hesemann, G. Moutiers, C. Mariet, A. Labet and J. C. Bunzli, Eur. J. Inorg. Chem., 2004, 1190.

25. I. Grenthe, J. Fuger, R. J. M. Konings, R. J. Lemire, A. B. Muller, C. Nguyen-Trung and H. Wanner, Chemical thermodynamics of uranium, OECD publication, 1992.

26. A. Ikeda, C. Hennig, A. Rossberg, S. Tsushima, A. C. Scheinost and G. Bernhard, Anal. Chem., 2008, 80, 1102.

27. C. Görller-Wallrand and S. De Jaegere, J. de Chimie Physique, 1972, 4, 726.

28. P. Nockemann, K. Servaes, R. V. Deun, K. V. Hecke, L. V. Meervelt, K. Binnemans and C. Görller-Walrand, Inorg. Chem., 2007, 46, 11335.

29. K. Servaes, C. Hennig, I. Billard, C. Gaillard, K. Binnemans, C. Görller-Wallrand and R. Van Deun, Eur. J. Inorg. Chem., 2007, 5120.

30. M. Bühl, R. Diss and G. Wipff, Inorg. Chem., 2007, 46, 5196.

31. A. E. Bradley, C. Hardacre, M. Nieuwenhuyzen, W. R. Pitner, D. Sanders, K. R. Seddon and R. C. Thied, Inorg. Chem., 2004, 43, 2503.

32. M.-O. Sornein, C. Cannes, C. Le Naour, G. Lagarde, E. Simoni and J.-C. Berthet, Inorg. Chem., 2006, 45, 10419.

33. P. G. Allen, J. J. Bucher, D. K. Shuh, N. M. Edelstein and T. Reich, Inorg. Chem., 1997, 36, 4676.

34. V. Cocalia, M. Smiglak, S. P. Kelley, J. L. Shamshina, G. Gurau and R. D. Rogers, Eur. J. Inorg. Chem., 2010, 2760.

35. I. Billard, C. Gaillard and C. Hennig, Dalton Trans., 2007, 4214.

36. P. Thuéry, Cryst. Growth Des., 2009, 9, 1208.

37. D. E. Irish, R. Pursel, N. J. Taylor and G. E. Toogood, acta Cryst. C, 1985, 41, 1012.

38. M. Newville, B. Ravel, D. Haskel, J. J. Rehr, A. Stern and Y. Yacoby, Physica B, 1995, 208-209, 154. 


\section{TABLES AND FIGURES}

\section{Table captions:}

Table 1: Description of calculated paths by FEFF8 for the complex $\left[\mathrm{UO}_{2}\left(\eta^{2}-\mathrm{NO}_{3}\right)_{2}\left(\eta^{1}-\mathrm{NO}_{3}\right)_{2}\right]^{2-}$, from ref. ${ }^{31}$

Table 2: Best fit results of EXAFS spectra for the two analyzed spectra. $R_{\text {factor }}$ represents the goodness of the fit as defined in ${ }^{38}$.

Table 3: Summary of crystallographic structure for $\left[\mathrm{UO}_{2}\left(\eta^{2}-\mathrm{NO}_{3}\right)_{2}\left(\eta^{1}-\mathrm{NO}_{3}\right)_{2}\right]^{2-}$ species obtained in the solid state and comparison with structural parameters obtained in this study

\section{Figure captions:}

Figure 1: EXAFS (top) and corresponding Fourier transforms (bottom) obtained at the $\mathrm{U}_{\mathrm{III}}$ edge of $\mathrm{UO}_{2}\left(\mathrm{NO}_{3}\right) \cdot 6 \mathrm{H}_{2} \mathrm{O}$ in $[\mathrm{BMI}]\left[\mathrm{NO}_{3}\right]$ and $\mathrm{UO}_{2}\left(\mathrm{Tf}_{2} \mathrm{~N}\right)_{2}$ in $[\mathrm{BMI}]\left[\mathrm{NO}_{3}\right]$, comparison with spectra obtained in $[\mathrm{BMI}]\left[\mathrm{Tf}_{2} \mathrm{~N}\right]$ of $\mathrm{UO}_{2}\left(\mathrm{NO}_{2}\right)_{2}$ and $\mathrm{UO}_{2}\left(\mathrm{NO}_{3}\right)_{3}{ }^{-}$complexes. ${ }^{20}$

\section{Supplementary information:}

- Experimental procedure

- Figure S1: Scheme of $\left.\mathrm{UO}_{2}\left(\eta^{2}-\mathrm{NO}_{3}\right)_{2}\left(\eta^{1}-\mathrm{NO}_{3}\right)_{2}\right]^{2-}$. 
Table 1: Description of calculated paths by FEFF8 for the complex $\left[\mathrm{UO}_{2}\left(\eta^{2}-\mathrm{NO}_{3}\right)_{2}\left(\eta^{1}-\mathrm{NO}_{3}\right)_{2}\right]^{2-}$, from ref. ${ }^{31}$

\begin{tabular}{|c|c|c|}
\hline Path description $^{(a)}$ & Distance $(\AA)$ & Amplitude ratio from $\mathrm{FEFF}^{(\mathrm{b})}$ \\
\hline $\mathrm{U}-\mathrm{O}_{\mathrm{ax}}$ & 1.765 & 100 \\
\hline $\mathrm{U}-\mathrm{O}_{\mathrm{eq}}$ monodentate & 2.428 & 39 \\
\hline $\mathrm{U}-\mathrm{O}_{\mathrm{eq}}$ bidentate & 2.525 & 35 \\
\hline U-N bidentate & 2.968 & 20 \\
\hline U-N monodentate & 3.329 & 14 \\
\hline $\mathrm{U}^{-\mathrm{O}_{\text {distal }}}$ monodentate & 3.412 & 13 \\
\hline $\mathrm{U}-\mathrm{O}_{\mathrm{eq}} \mathrm{-N}$ monodentate & 3.530 & 12 \\
\hline $\mathrm{U}-\mathrm{O}_{\mathrm{ax}}-\mathrm{U}-\mathrm{O}_{\mathrm{ax}}$ & 3.529 & 69 \\
\hline $\mathrm{U}_{-} \mathrm{O}_{\text {distal }}$ bidentate & 4.178 & 6 \\
\hline $\mathrm{U}-\mathrm{O}_{\text {distal }}-\mathrm{N}$ bidentate & 4.178 & 20 \\
\hline $\mathrm{U}-\mathrm{N}-\mathrm{O}_{\text {distal }}-\mathrm{N}$ bidentate & 4.178 & 15 \\
\hline
\end{tabular}

(a) "ax" is for "axial", "eq" is for equatorial, "monodentate" and "bidentate" indicate the mode of nitrate groups complexation in the uranium equatorial shell.

(b) Paths amplitude is normalized with respect to the highest amplitude, which is set to $100 \%$.

Table 2: Best fit results of EXAFS spectra for the two analyzed spectra. $\mathrm{R}_{\text {factor }}$ represents the goodness of the fit as defined in ${ }^{38}$. * indicates fixed parameters during the fit.

\begin{tabular}{|c|c|c|c|c|c|c|}
\hline \multirow{2}{*}{ shell } & \multicolumn{3}{|c|}{$\mathrm{UO}_{2}\left(\mathrm{Tf}_{2} \mathrm{~N}\right)_{2}$ in $[\mathrm{BMI}]\left[\mathrm{NO}_{3}\right]$} & \multicolumn{3}{|c|}{$\mathrm{UO}_{2}\left(\mathrm{NO}_{3}\right)_{3}$ in $[\mathrm{BMI}]\left[\mathrm{NO}_{3}\right]$} \\
\hline & $\mathrm{N}$ & $R(\AA)$ & $\sigma^{2}\left(\AA^{2}\right)$ & $\mathrm{N}$ & $\mathrm{R}(\AA)$ & $\sigma^{2}\left(\AA^{2}\right)$ \\
\hline U-O $\mathrm{O}_{\text {axial }}$ & $2 *$ & $1.76(5)$ & $0.001(9)$ & $2 *$ & $1.76(3)$ & $0.001(1)$ \\
\hline U-O eq-monodentate & $2.4(6)$ & $2.40(1)$ & $0.008(1)$ & $2.7(1)$ & $2.41(7)$ & $0.008(8)$ \\
\hline U-O eq-bidentate & $3.6(4)$ & $2.53(4)$ & $0.005(5)$ & $3.3(1)$ & $2.54(2)$ & $0.003(6)$ \\
\hline U-N $\mathrm{N}_{\text {bidentate }}$ & $1.8(1)$ & $2.97(9)$ & $0.005(3)$ & $1.6(5)$ & $2.92(5)$ & $0.003(2)$ \\
\hline U-N $\mathrm{N}_{\text {monodentate }}$ & $2.4(6)$ & $3.27(1)$ & $0.012(3)$ & $2.7(1)$ & $3.14(8)$ & $0.013(7)$ \\
\hline U-O dist-monodentate & $2.4(6)$ & $3.45(3)$ & $0.004(4)$ & $2.7(1)$ & $3.42(2)$ & $0.005(9)$ \\
\hline U-O dist-bidentate & $1.8(2)$ & $4.19(1)$ & $0.003(2)$ & $1.6(5)$ & $4.20(1)$ & $0.003(3)$ \\
\hline $\mathrm{E}_{0}(\mathrm{eV})$ & \multicolumn{3}{|c|}{-9.9} & \multicolumn{3}{|c|}{-10.0} \\
\hline $\mathrm{R}_{\text {factor }}$ & \multicolumn{3}{|c|}{0.02} & \multicolumn{3}{|c|}{0.01} \\
\hline
\end{tabular}


Table 3: Summary of crystallographic structure for $\left[\mathrm{UO}_{2}\left(\eta^{2}-\mathrm{NO}_{3}\right)_{2}\left(\eta^{1}-\mathrm{NO}_{3}\right)_{2}\right]^{2-}$ species obtained in the solid state and comparison with structural parameters obtained in this study.

\begin{tabular}{|c|c|c|c|c|c|c|c|c|}
\hline & \multicolumn{4}{|c|}{ Monodentate nitrate groups } & \multicolumn{4}{|c|}{ Bidentate nitrate groups } \\
\hline & $\begin{array}{c}\mathrm{U}-\mathrm{O}_{\text {eq }} \\
(\AA)\end{array}$ & $\begin{array}{l}\mathrm{U}-\mathrm{N} \\
(\AA)\end{array}$ & $\begin{array}{c}\mathrm{U}-\mathrm{Od}_{\text {istal }} \\
(\AA)\end{array}$ & $\begin{array}{c}\text { Angle } \\
\mathrm{O}_{\mathrm{eq}}-\mathrm{N}-\mathrm{O}_{\text {distal }}\end{array}$ & $\begin{array}{l}\mathrm{U}-\mathrm{O}_{\text {eq }} \\
(\AA)\end{array}$ & $\begin{array}{l}\text { U-N } \\
(\AA)\end{array}$ & $\begin{array}{c}\mathrm{U}^{\mathrm{U}-\mathrm{Od}_{\text {istal }}} \\
(\AA)\end{array}$ & $\begin{array}{c}\text { Angle } \\
\mathrm{O}_{\mathrm{eq}}-\mathrm{N}-\mathrm{O}_{\text {distal }}\end{array}$ \\
\hline $\begin{array}{c}\text { Thuery et al. }{ }^{36} \\
A\end{array}$ & 2.427 & 2.918 & 3.067 & $124^{\circ}$ & $\begin{array}{l}2.533- \\
2.571\end{array}$ & 2.902 & 4.221 & $123^{\circ}$ \\
\hline $\begin{array}{c}\text { Thuery et al. } \\
B \\
\end{array}$ & 2.410 & 3.144 & 3.465 & $132^{\circ}$ & $\begin{array}{l}2.483- \\
2.569 \\
\end{array}$ & 2.972 & 4.246 & $114^{\circ}$ \\
\hline $\begin{array}{c}\text { Bradley et al. }{ }^{31} \\
C\end{array}$ & 2.426 & 3.340 & 3.511 & $120^{\circ}$ & $\begin{array}{l}2.514- \\
2.510\end{array}$ & 2.953 & 4.154 & $115^{\circ}$ \\
\hline $\begin{array}{c}\text { Bradley et al. }{ }^{31} \\
D\end{array}$ & $\begin{array}{l}2.425- \\
2.431\end{array}$ & $\begin{array}{l}3.340- \\
3.319\end{array}$ & $\begin{array}{l}3.442- \\
3.383\end{array}$ & $120^{\circ}$ & $\begin{array}{l}2.543- \\
2.505\end{array}$ & 2.967 & 4.178 & $115^{\circ}$ \\
\hline $\begin{array}{c}\text { Irish et al. }^{37} \\
C\end{array}$ & 2.403 & 3.34 & $\begin{array}{c}3.750- \\
4.210 \\
\end{array}$ & $117^{\circ}$ & 2.515 & 2.960 & 4.175 & $123^{\circ}$ \\
\hline $\begin{array}{c}\text { This work } \\
\mathrm{UO}_{2}\left(\mathrm{Tf}_{2} \mathrm{~N}\right)_{2} \text { in } \\
{[\mathrm{BMI}]\left[\mathrm{NO}_{3}\right]}\end{array}$ & 2.401 & 3.27 & 3.45 & - & 2.53 & 2.97 & 4.19 & - \\
\hline $\begin{array}{c}\text { This work } \\
\mathrm{UO}_{2}\left(\mathrm{NO}_{3}\right)_{2} \cdot 6 \mathrm{H}_{2} \mathrm{O} \\
\text { in }[\mathrm{BMI}]\left[\mathrm{NO}_{3}\right]\end{array}$ & 2.41 & 3.14 & 3.42 & - & 2.54 & 2.92 & 4.20 & - \\
\hline
\end{tabular}



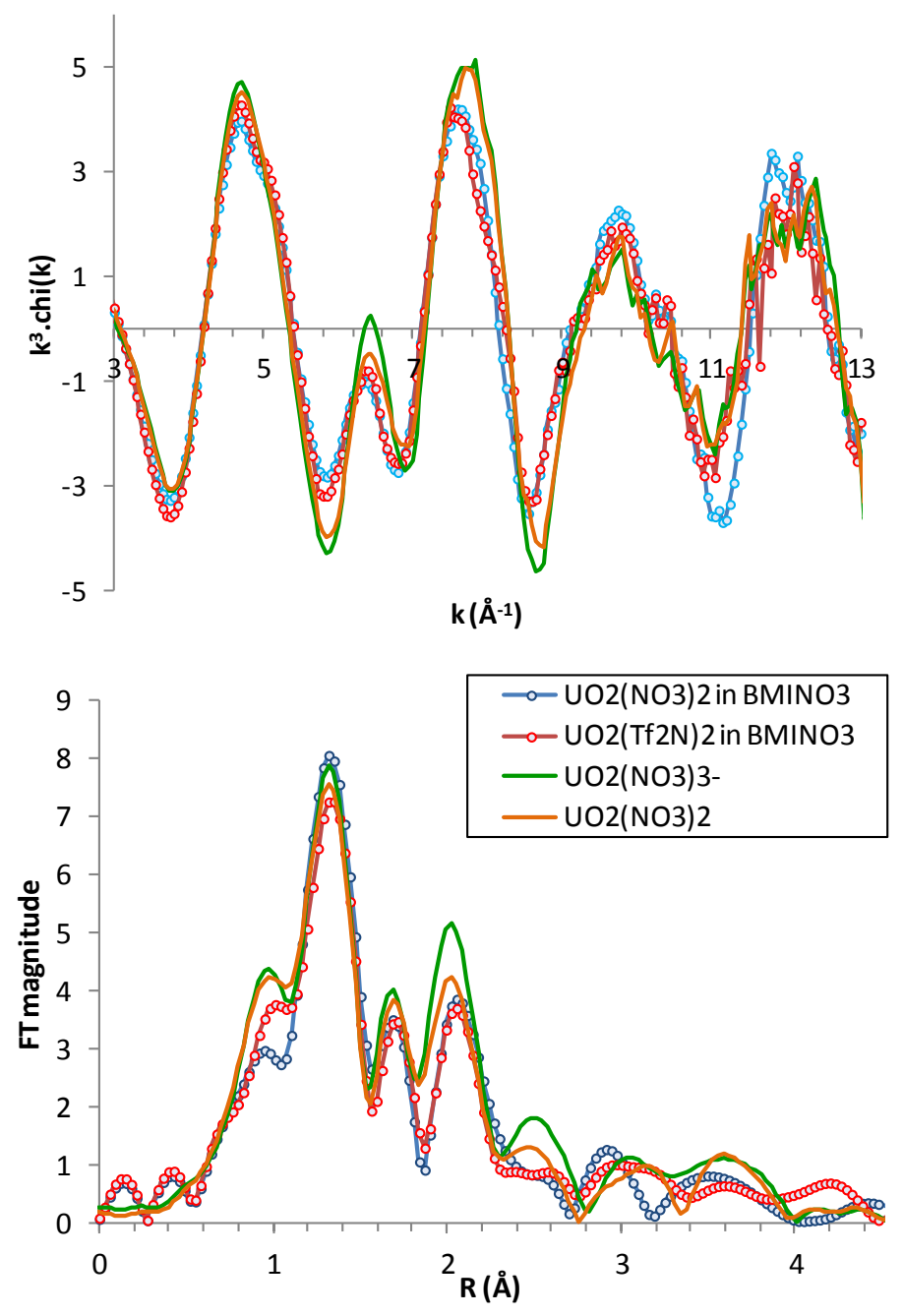

Figure 1: EXAFS (top) and corresponding Fourier transforms (bottom) obtained at the $\mathrm{U}_{\mathrm{III}}$ edge of $\mathrm{UO}_{2}\left(\mathrm{NO}_{3}\right) \cdot 6 \mathrm{H}_{2} \mathrm{O}$ in $[\mathrm{BMI}]\left[\mathrm{NO}_{3}\right]$ and $\mathrm{UO}_{2}\left(\mathrm{Tf}_{2} \mathrm{~N}\right)_{2}$ in $[\mathrm{BMI}]\left[\mathrm{NO}_{3}\right]$, comparison with spectra obtained in $[\mathrm{BMI}]\left[\mathrm{Tf}_{2} \mathrm{~N}\right]$ of $\mathrm{UO}_{2}\left(\mathrm{NO}_{2}\right)_{2}$ and $\mathrm{UO}_{2}\left(\mathrm{NO}_{3}\right)_{3}{ }^{-}$complexes. ${ }^{20}$ 